\title{
The Use of High-dose Corticosteroids in Seriously III Children with Acute Viral Bronchiolitis
}

\author{
Şiddetli Akut Viral Bronşiyoliti Olan Çocuklarda Yüksek Doz Kortikosteroidlerin Kullanımı
}

\author{
(1) Çelebi Kocaoğlu \\ Konya Training and Research Hospital, Clinic of Pediatric Intensive Care, Konya, Turkey
}

\section{Abstract}

Introduction: The aim of the present study is to investigate whether high-dose corticosteroids cause a clinical improvement in seriously ill children with acute viral bronchiolitis.

Methods: Hospital records of patients diagnosed with acute viral bronchiolitis and admitted to the pediatric intensive care unit or general pediatrics service in a tertiary care hospital were reviewed retrospectively. Patients receiving steroids were divided into two subgroups: high-dose and standard-dose corticosteroid recipients. Patients diagnosed with acute viral bronchiolitis but receiving no corticosteroid treatment constituted the control group.

Results: While there was no difference between the pre- and postdrug pulse rates of all three groups, a difference was observed in both pre- and post-drug breathing rates between the high-dose steroid and control groups. However, there was no difference between the average pre- and post-drug breathing rates in the highdose steroid, standard-dose steroid and control groups. There was no regression relationship between the treatment applied and either the pulse rate or the breathing rate in the entire study group.

Conclusion: The results of our study show that even at high doses, corticosteroids provide no obvious improvement in the patient's clinical status and do not shorten the length of hospitalisation.

Keywords: Bronchiolitis, children, corticosteroid, high-dose, treatment

\section{Öz}

Giriş: Çalışmanın amacı akut viral bronşiyolitle ciddi şekilde hasta çocuklarda yüksek doz kortikosteroidlerin klinik iyileşmeye neden olup olmadığının araştııılmasıdır.

Yöntemler: Akut viral bronşiyolit tanısı konulan ve üçüncü basamak çocuk yoğun bakım ünitesine veya genel çocuk servisine alınan hastaların, hastane kayıtları geriye dönük olarak incelendi. Steroid tedavisi alan hastalar, yüksek doz ve standart doz kortikosteroid alanlar olmak üzere iki alt gruba ayrıldı. Akut viral bronşiyolit tanısı konulan ancak kortikosteroid tedavisi almayan hastalar, kontrol grubunu oluşturdu.

Bulgular: Üç grubun ilaç öncesi ve sonrası nabız hızları arasında hiç bir fark yok iken, solunum hızları arasında fark gözlendi. Bu fark, yüksek doz steroid grubu ile kontrol grubu arasındaydı. Bununla birlikte hem yüksek doz steroid, hem standart doz steroid, hem de kontrol grubunda ilaç öncesi ve ilaç sonrası solunum hızları arasında fark yoktu. Tüm çalışma grubunda uygulanan tedavi ile nabız hızı ve solunum hızı arasında hiç bir neden sonuç ilişkisi yoktu.

Sonuç: Çalışmamızın sonuçları gösterdi ki, kortikosteroidler yüksek dozlarda bile hastanın klinik durumunda düzelme ve hastanede kalış süresini kısaltma noktasında istatistiksel anlamda bir iyileşme sağlamamaktadır.

Anahtar Kelimeler: Bronşiyolit, çocuklar, kortikosteroid, yüksek doz, tedavi

\section{Introduction}

Acute viral respiratory tract infections, especially viral bronchiolitis, are among the most common reasons for admission to hospital in the first 24 months of life. Many viruses, including respiratory syncytial virus, rhinovirus, adenovirus, coronavirus, metapneumovirus, bocavirus, parainfluenza virus, seasonal H1N1 and H3N2 viruses, may lead to respiratory tract infections. However, the correlation between the disease severity and isolated virus is not consistent most of the time. Bronchiolitis is characterised by inflammation, oedema and extensively increased mucus secretion in the airway, and as a

Yazışma Adresi/Address for Correspondence: Çelebi Kocaoğlu, Konya Training and Research Hospital, Department of Pediatric Intensive Care, Konya, Turkey E-posta: celebikocaoglu@hotmail.com ORCID ID: orcid.org/0000-0002-6928-9186

Geliş Tarihi/Received: 06.12.2018 Kabul Tarihi/Accepted: 09.05.2019

-Telif Hakkı 2020 Çocuk Acil Tıp ve Yoğun Bakım Derneği

Çocuk Acil ve Yoğun Bakım Dergisi, Galenos Yayınevi tarafından yayınlanmıştır. 
result leads to different degrees of obstruction, air trapping and alveolar collapse. ${ }^{1}$

The symptoms of bronchiolitis include fever, cough, dyspnoea, tachypnoea and apnoea. The physical examination reveals wheeze and increased work of breathing, including supraclavicular, intercostal and subcostal retractions, and nasal flaring. Nevertheless, these symptoms and findings are usually intricate in children with acute viral respiratory tract infections, and the differential diagnosis is difficult.

The anti-inflammatory effects of corticosteroids are wellknown; in addition, corticosteroids also have a vasoconstrictive effect that may contribute to their clinical benefit by resulting in reduced airway oedema and less microvascular leakage. ${ }^{2}$ Corticosteroids are widely used for the treatment of respiratory disorders associated with airway inflammation in the practice of paediatrics. However, the evidence supporting the use of corticosteroids with these indications remains controversial. . $^{3-5}$

Although numerous studies have explored the benefits of corticosteroids to treat children with bronchiolitis, the effectiveness of high doses of these medications has yet to be examined. ${ }^{6,7}$ The aim of present study is to investigate whether high-dose corticosteroids cause the clinical improvement in seriously ill children with acute viral bronchiolitis.

\section{Materials and Methods}

Information on patients diagnosed with acute viral bronchiolitis at the age of 0 to 3 years, evaluated in general paediatric and paediatric intensive care units from 2012 to 2017 and receiving corticosteroid therapy, were assessed retrospectively. Patients receiving corticosteroids were divided into two subgroups: high-dose $(10 \mathrm{mg} / \mathrm{kg})$ and standarddose $(2 \mathrm{mg} / \mathrm{kg})$ methyl-prednisolone recipients. The choice of treatment was determined by clinicians according to the Respiratory Distress Assessment Instrument Score and the patient's clinical status. The control group was created from patients diagnosed with bronchiolitis but not receiving steroid treatment. Meanwhile, all patients received humidified oxygen, inhaled salbutamol and hydration therapy as the standard treatment.

Patients with mild bronchiolitis (defined by a Respiratory Distress Assessment Instrument score <6), congenital heart disease, bacterial pneumonia and chronic pulmonary disease, and those with congenital airway abnormalities such as a vascular ring and those diagnosed with foreign bodies were excluded from the study. Likewise, patients with fever were also excluded from the study by considering that it might affect their vital findings. At enrolment and for 6 hours after administration of the standard treatment protocol, patients' vital signs, such as temperature, heart and respiratory rates, and oxygen saturation levels, were recorded. For patients with multiple measurements, the average calculations were accepted. The length of hospital stay was also evaluated in the study.

The hospital records of about 500 patients diagnosed with acute viral bronchiolitis and admitted to the hospital were reviewed, and 230 patients receiving corticosteroid therapy were enrolled in the study. Nevertheless, 70 cases were removed because of exclusion criteria or data irregularity. So, the study was completed with the hospital records of 160 patients.

\section{Statistical Analysis}

Statistical analyses were performed using SPSS for Windows, release 22.0 (SPSS, Chicago, IL). The normality of the data was tested using the Kolmogorov-Smirnov test. The MannWhitney $\mathrm{U}$ test was used to compare mean values. The KruskalWallis test was used to compare mean values in categorised patient groups. Regression analysis was performed using the multiple regression analysis test. The results were expressed as mean \pm standard deviation, and statistical significance was accepted as $p<0.05$. The study was approved by the local ethics committee.

\section{Results}

The entire study group consisted of 160 patients. Of the patients receiving corticosteroids, $74(46.3 \%)$ had received high-dose methyl-prednisolone, while 36 (22.5\%) had received the standard-dose. The control group receiving no corticosteroid treatment was composed of 50 (31.3\%) patients (Table 1). The mean age of the cases in the entire study group was 21.4 \pm 7.3 months [minimum (min) 12, maximum (max) 36]. The mean age rates of the cases in the high-dose, standard-dose and control groups were 21.1 \pm 6.9 , $21.5 \pm 7.6$ and $21.9 \pm 7.9$, respectively. There was no difference between the average ages of the three groups.

Table 1. Demographic features of the study groups

\begin{tabular}{|l|l|l|l|l|l|}
\hline \multicolumn{2}{|l|}{} & $\begin{array}{l}\text { Entire study group } \\
(\mathbf{n = 1 6 0 )}\end{array}$ & $\begin{array}{l}\text { High-dose } \\
(\mathbf{n = 7 4 )}\end{array}$ & $\begin{array}{l}\text { Standard-dose } \\
(\mathbf{n}=\mathbf{3 6})\end{array}$ & Control group (n=50) \\
\hline \multirow{2}{*}{ Mean age (month) } & $21.4 \pm 7.3$ & $21.1 \pm 6.9$ & $21.5 \pm 7.6$ & $21.9 \pm 7.9$ \\
\hline \multirow{2}{*}{ Gender } & Male, $\mathrm{n}(\%)$ & $88(55 \%)$ & $40(54.1 \%)$ & $24(66.7 \%)$ & $24(48 \%)$ \\
\cline { 2 - 7 } & Female, $\mathrm{n}(\%)$ & $72(45 \%)$ & $34(45.9 \%)$ & $12(33.3 \%)$ & $26(52 \%)$ \\
\hline
\end{tabular}


Of all cases in the entire study group, 88 (55\%) were boys, while 72 (45\%) were girls. Of the high-dose group, 40 $(54.1 \%)$ were male, and 34 (45.9\%) were female. Among the standard-dose group, 24 (66.7\%) were male, and 12 (33.3\%) were female. Of the controls, 24 (48\%) were male, and 26 $(52 \%)$ were female.

The average pre-drug heart rate of the entire study group was 148.1 \pm 18.4 ( $\min 100, \max 200$ ) (Table 2). The average pre-drug heart rates of the high-dose, standard-dose and control groups were found to be $150 \pm 19.7,150.7 \pm 17.9$ and $143.4 \pm 16.3$, respectively. There was no difference in pre-drug pulse rates between the three groups. The post-drug heart rate average of the entire study group was $138.8 \pm 16.5$ ( $\mathrm{min}$ 80 , max 173). The post-drug heart rate averages of the highdose group, standard-dose group and control group were $140.4 \pm 18.6,138.7 \pm 15$ and $136.5 \pm 14$, respectively. There was no difference in post-drug pulse rates between the three groups. There was a difference between average pre- and postdrug pulse rates in entire study group $(p<0.05)$. In the same way, there was a difference between the average pre- and post-drug pulse rates of both high-dose and standard-dose corticosteroid groups, and those of the controls $(p<0.05)$.

The average pre-drug breathing rate of the entire study group was $33.7 \pm 8$ ( $\min 20$, $\max 65)$. The average pre-drug breathing rates of the high-dose, standard-dose and control groups were $35.5 \pm 8.5,34.2 \pm 9.3$ and $30.6 \pm 5$, respectively. A difference was observed between the high-dose steroid group and the control group in terms of pre-drug breathing rates $(p<0.05)$. The average post-drug breathing rate of the entire study group was $32.6 \pm 7.6$ ( $\min 20, \max 75)$. The average post-drug breathing rates of the high-dose, standard-dose and control groups were found to be $34.5 \pm 8.3,33.5 \pm 9.2$ and $29.4 \pm 3.4$, respectively. There was a difference between the high-dose corticosteroid group and the control group as to post-drug breathing rates $(p<0.05)$. Although there was a difference between average pre- and post-drug breathing rates in the entire study group $(p<0.05)$, there was no difference between the average preand post-drug breathing rates of the high-dose, standard-dose and control groups.
The average pre-drug oxygen saturation $\left(\mathrm{SpO}_{2}\right)$ rate of the entire study group was $96.1 \pm 4$ ( $\min 76, \max 100)$. Pre-drug $\mathrm{SpO}_{2}$ averages of the high-dose, standard-dose and control groups were $95.3 \pm 4.5,96.9 \pm 4$ and $96.8 \pm 2.7$, respectively. There were no between-group differences in the average predrug $\mathrm{SpO}_{2}$ rate. The average post-drug $\mathrm{SpO}_{2}$ rate of the entire study group was $96.5 \pm 4$ ( $\min 78, \max 100)$. The average postdrug $\mathrm{SpO}_{2}$ rates of the high-dose, standard-dose and control groups were $95.8 \pm 4.3,96.9 \pm 4.6$ and $97.4 \pm 2.1$, respectively. There were no between-group differences in the average postdrug $\mathrm{SpO}_{2}$ rate. There was no difference between average pre- and post-drug $\mathrm{SpO}_{2}$ rates in the entire study group. In the same way, there was also no difference between average preand post-drug $\mathrm{SpO}_{2}$ rates in any of the groups.

The average length of hospital stay of the entire study group was $3.8 \pm 2.1$ days $(\min 1, \max 11)$. The average lengths of hospital stay of the high-dose, standard-dose and control groups were $4.8 \pm 2.4,3.3 \pm 1.5$ and $3.04 \pm 1.4$ days, respectively. There was a difference between the average length of hospital stay $(p<0.05)$ between the high-dose and control groups, and between the high-dose and standard-dose corticosteroid groups. No difference was observed between the standarddose group and the control group.

There was no regression relationship between the treatment applied and the post-drug pulse rate and post-drug breathing rates in entire study group.

\section{Discussion}

The use of corticosteroids in the management of children with acute bronchiolitis is still controversial. In a study published by Plint et al. ${ }^{5}$, it is reported that the combination of nebulised epinephrine with oral dexamethasone administered was superior to a placebo in terms of the prevention of hospital admission. However, in a study performed by Corneli et al. ${ }^{4}$, it is reported that dexamethasone did not significantly alter the rate of hospital admission. Even so, the opinion that corticosteroids are ineffective and should not be used has come into prominence in recent times. ${ }^{3,8}$ The American

Table 2. Comparison the clinical parameters of the study groups

\begin{tabular}{|c|c|c|c|c|c|}
\hline Clinical parameters & Entire study group & High-dose & Standard-dose & Control & $\mathbf{p}$ \\
\hline Pre-drug heart rate & $148.1 \pm 18.4$ & $150 \pm 19.7$ & $150.7 \pm 17.9$ & $143.4 \pm 16.3$ & $>0.05$ \\
\hline Post-drug heart rate & $138.8 \pm 16.5$ & $140.4 \pm 18.6$ & $138.7 \pm 15$ & $136.5 \pm 14$ & $>0.05$ \\
\hline Post-drug breath rate & $32.6 \pm 7.6$ & $34.5 \pm 8.3$ & $33.5 \pm 9.2$ & $29.4 \pm 3.4$ & $<0.05^{\star}$ \\
\hline Pre-drug $\mathrm{SpO}_{2}$ rate & $96.1 \pm 4$ & $95.3 \pm 4.5$ & $96.9 \pm 4$ & $96.8 \pm 2.7$ & $>0.05$ \\
\hline
\end{tabular}


Academy of Pediatrics recommends no administration of systemic corticosteroids in infants with acute bronchiolitis. ${ }^{9}$

Although corticosteroids have been beneficial at a higher rate in children with diseases such as viral croup, they have been less effective against other diseases. The utilisation of corticosteroid treatment for preschool children with acute episodic wheeze still remains controversial., ${ }^{5,8}$ A lack of response to corticosteroids may be due to the heterogeneity of wheezing aetiology. It can be speculated that, generally, this response is more obvious when airway inflammation is at the forefront. ${ }^{2}$ However, it is sometimes difficult to make a differential diagnosis among clinically acute bronchiolitis, viral pneumonia, croup and acute episodic wheeze. In such cases, testing the patient's corticosteroid response and, if a response is observed, continuing treatment may be an alternative method.

The synergy between corticosteroids and $\beta 2$-agonists is well-documented, especially in the treatment of asthma. $\beta 2$-agonists enhance glucocorticoid-dependent transcription in airway epithelial and smooth muscle cells by increasing the simple glucocorticoid response to element-dependent transcription via the classical cyclic adenosine monophosphateactivated protein kinase pathway. ${ }^{10}$ It is likely that combined therapy with nebulised salbutamol and corticosteroids may reduce the symptoms and signs of bronchiolitis via a similar mechanism. The fact that in our study there was no difference in terms of clinical response between the groups receiving high-dose corticosteroid and standard-dose corticosteroid, and the controls receiving no corticosteroid suggested that this synergy was specific to asthma, and there was no such synergy in bronchiolitis. However, more comprehensive studies are needed to ascertain whether this combined therapy is beneficial in the treatment of acute viral bronchiolitis. We could not comment on this relationship because our study was retrospective.

In some studies, the authors suggest that the antipyretic effect of corticosteroids may account for differences in the heart rate. ${ }^{11}$ In our study, there was a difference between preand post-drug pulse numbers of the high-dose and standarddose corticosteroid group, and the control group receiving no corticosteroid therapy. Therefore, we cannot agree with this idea. We consider that this reduction in pulse rate arose from the improvement in the patient's clinical condition due to the standard treatment applied rather than the anti-inflammatory effect of corticosteroids. This decrease in pulse rate may even be due to the fact that the patient's anxiety in the first hospitalisation declines over time, like the white coat effect.

In their study, Plint et al. ${ }^{5}$ reported that patients given combined therapy consisting of dexamethasone and epinephrine experienced shorter durations of hospital stay and resumed quiet breathing earlier than those in the placebo group. The authors associated this effect with the synergy between dexamethasone and epinephrine. In our study, patients in three groups received standard treatment consisting of oxygen, nebulised salbutamol and IV fluids. Our standard treatment protocol did not include the application of nebulised epinephrine. In accordance with the recommendations of the American Academy of Pediatrics Subcommittee, our patients received bronchodilation (salbutamol) therapy in addition to corticosteroid therapy. ${ }^{12}$ So, we cannot comment on the synergistic effect of epinephrine and dexamethasone. However, in our study, such synergy was not observed between corticosteroids and nebulised salbutamol.

However, Schuh et al. ${ }^{13}$ reported that the respiratory scores were reduced at significant levels in infants receiving dexamethasone, as compared with those in the placebo group. In addition, the admission rate was also lower in the dexamethasone group. In a Cochrane review performed by Fernandes et al. ${ }^{8}$, it is asserted that the evidence supports a clinically relevant effect of systemic glucocorticoids on neither admissions nor length of hospitalisation when used alone in patients with bronchiolitis. However, combined dexamethasone and epinephrine may reduce outpatient admission, but the results are exploratory, and the safety data are limited. The results of our study were consistent with the notion put forward by Fernandes et al. ${ }^{8}$.

Our study has several limitations. First, we anticipated no synergistic effect between corticosteroids and drugs used in standard treatment before our study. Second, the control group and children treated with corticosteroids did not have the same level of disease severity, because corticosteroid therapy was applied to those with more severe disease. It was unlikely that children with clinically more severe illnesses would be deprived of the optimal treatment strategy due to ethical concerns.

Although numerous studies have explored the benefit of corticosteroids to treat children with bronchiolitis, the effectiveness of high doses of these medications has yet to be examined. The distinguishing feature of our study is that it was performed with inpatients, and our treatment regime was composed of high-dose prednisolone, inhaled salbutamol, nasal oxygen and IV fluid therapy. The results of our study showed that even at high doses, corticosteroids provide no obvious improvement in the patient's clinical picture and do not shorten the length of hospitalisation.

\section{Study Limitations}

Our study has some limitations precluding us from reaching strong conclusions. The weakness of this study was the 
small number of patients. In addition, there was no standard regarding the effect of patients' emotional state on their vital signs, and it was not possible to control this situation.

\section{Conclusion}

The reason for the differences in responses to corticosteroids remains unclear. It is possible that the different disease processes, such as acute bronchiolitis, viral pneumonia, croup, acute episodic wheeze and probably viral co-infection, are responsible for this ambiguity. It is understood from previous studies that each clinic has its own treatment protocol for the treatment of bronchiolitis. Whichever treatment protocol is applied, a clinical improvement is witnessed in patients because of the self-limiting characteristic of the disease. We consider that this situation prevents the creation of a definitive treatment protocol. So, more comprehensive studies must be performed before recommending any change in the use of corticosteroids in children with acute viral bronchiolitis.

\section{Ethics}

Ethics Committee Approval: The study was approved by the local ethics committee.

Informed Consent: Informed consent was not obtained from the patients, as approved by the Regional Ethics Committee of Konya Training and Research Hospital, Turkey (Record no: 2017/1058).

Peer-review: Externally peer reviewed.

Financial Disclosure: The authors declared that this study received no financial support.

\section{References}

1. Ali S, Plint AC, Klassen TP. Bronchiolitis. In: Wilmott RW, Kendig EL, Boat TF, Bush A, Chernick V, eds. Kendig and Chernick's disorders of the respiratory tract in children, 8th ed. Philadelphia: Elsevier Saunders. 2012; 443-52.
2. Beigelman A, Chipps BE, Bacharier LB. Update on the utility of corticosteroids in acute pediatric respiratory disorders. Allergy Asthma Proc. 2015;36:332-8.

3. Florin TA, Plint AC, Zorc JJ. Viral bronchiolitis. Lancet. 2017;389:21124.

4. Corneli HM, Zorc JJ, Mahajan P, Shaw KN, Holubkov R, et al. Bronchiolitis Study Group of the Pediatric Emergency Care Applied Research Network (PECARN). A multicenter, randomized, controlled trial of dexamethasone for bronchiolitis. N Engl J Med. 2007; 357: 331-9.

5. Plint $A C$, Johnson DW, Patel $H$, Wiebe $N$, Correll $R$, et al. Pediatric Emergency Research Canada (PERC). Epinephrine and dexamethasone in children with bronchiolitis. N Engl J Med. 2009;360:2079-89

6. Kua KP, Lee SWH. Systematic review and meta-analysis of the efficacy and safety of combined epinephrine and corticosteroid therapy for acute bronchiolitis in infants. Front Pharmacol. 2017;8:396.

7. Cutrera R, Baraldi E, Indinnimeo L, Miraglia Del Giudice M, Piacentini $G$, et al. Management of acute respiratory diseases in the pediatric population: the role of oral corticosteroids. Ital J Pediatr. 2017;43:31

8. Fernandes RM, Bialy LM, Vandermeer B, Tjosvold L, Plint AC, et al. Glucocorticoids for acute viral bronchiolitis in infants and young children. Cochrane Database Syst Rev. 2013;CD004878.

9. Ralston SL, Lieberthal AS, Meissner HC, Alverson BK, Baley JE, et al. American Academy of Pediatrics. Clinical practice guideline: the diagnosis, management, and prevention of bronchiolitis. Pediatrics. 2014;134:e1474-502.

10. Kaur M, Chivers JE, Giembycz MA, Newton R. Long-acting beta2adrenoceptor agonists synergistically enhance glucocorticoiddependent transcription in human airway epithelial and smooth muscle cells. Mol Pharmacol. 2008;73:203-14.

11. Hanna CM, Greenes DS. How much tachycardia in infants can be attributed to fever? Ann Emerg Med. 2004;43:699-705.

12. American Academy of Pediatrics Subcommittee on Diagnosis and Management of Bronchiolitis. Diagnosis and management of bronchiolitis. Pediatrics. 2006;118:1774-93.

13. Schuh S, Coates AL, Binnie R, Allin T, Goia C, et al. Efficacy of oral dexamethasone in outpatients with acute bronchiolitis. J Pediatr. 2002;140:27-32. 